\title{
Thermocline fluctuations in the western tropical Indian Ocean during the past $35 \mathrm{ka}$
}

\author{
NADINE RIPPERT, ${ }^{1} *$ KARL-HEINZ BAUMANN ${ }^{2}$ and JÜRGEN PÄTZOLD ${ }^{3}$ \\ ${ }^{1}$ Alfred Wegener Institute Helmholtz Centre for Polar and Marine Research, 27568, \\ Bremerhaven, Germany \\ ${ }^{2}$ Faculty of Geosciences, University of Bremen, Bremen, Germany \\ ${ }^{3}$ MARUM - Center for Marine Environmental Sciences and Faculty of Geosciences, \\ University of Bremen, Bremen, Germany
}

Received 21 August 2014; Revised 19 January 2015; Accepted 21 January 2015

\begin{abstract}
To reconstruct the still poorly understood thermocline fluctuations in the western tropical Indian Ocean, a sediment core located off Tanzania (GeoB12610-2; 04 $49.00^{\prime} \mathrm{S}, 39^{\circ} 25.42^{\prime} \mathrm{E}, 399 \mathrm{~m}$ water depth) covering the last $35 \mathrm{ka}$ was analysed. $\mathrm{Mg} /$ Ca-derived temperatures from the planktonic foraminifera Globigerinoides ruber (white) and Neogloboquadrina dutertrei indicate that the last glacial was $\sim 2.5^{\circ} \mathrm{C}$ colder in the surface waters and $\sim 3.5^{\circ} \mathrm{C}$ colder in the thermocline compared with the present day. The depth of the thermocline and thus the stratification of the water column were shallower during glacial periods and deepened during the deglaciation and Holocene. The increased inflow of Southern Ocean Intermediate Waters via 'ocean tunnels' appears to cool the thermocline from below, leading to a similarity between the thermocline record of GeoB12610-2 with the Antarctic EDML temperature curve during the glacial. With rising sea level and the corresponding greater inflow of Red Sea Waters and Indonesian Intermediate Waters, the proportion of Southern Ocean Intermediate Water within the South Equatorial Current is reduced and, by Holocene time, the correlation to Antarctica is barely traceable. Comparison with the eastern Indian Ocean reveals that the thermocline depth reverses from the last glacial to present.

Copyright (C) 2015 John Wiley \& Sons, Ltd.
\end{abstract}

KEYWORDS: Indian Ocean; Mg/Ca; planktonic foraminifera; stratification; thermocline variations.

\section{Introduction}

Intermediate waters have been shown to play an important part in the global thermohaline circulation, as they transport waters from the Southern Ocean northward (e.g. Liu and Yang, 2003; Kessler, 2006; Bostock et al., 2010; Pena et al., 2013). In extratropical regions surface water masses are subducted ('thermocline ventilation') and transported northward along defined subsurface pathways ('ocean tunnels') into tropical regions where they eventually upwell (Liu and Yang, 2003). Thereby, the intermediate water masses from the south influence the physical (e.g. by temperature changes) and chemical (e.g. nutrient composition) properties of tropical intermediate waters (Kessler, 2006).

In recent decades the Indian Ocean has gained increasing attention regarding its role in global climate change (e.g. Kiefer et al., 2006; Fine et al., 2008; Pena et al., 2013), as it contributes to the global thermohaline circulation and to North Atlantic Deep Water formation by the input of heat and salt into the South Atlantic Ocean via thermocline and intermediate waters (Gordon et al., 1992). But the influencing mechanisms and components affecting the Indian Ocean intermediate waters, especially in the western Indian Ocean are still largely unknown.

A strong influence of Antarctic Intermediate Water (AAIW) and Subantarctic Mode Water (SAMW) on intermediate waters of the world's oceans has already been implied based on neodymium isotope variations for the western tropical Atlantic (Pahnke et al., 2008), on geochemical tracers, carbon isotopes and radiocarbon in the Pacific (Bostock et al., 2010), and on stable isotopes and $\mathrm{Mg} / \mathrm{Ca}$ measurements in the tropical Indian Ocean (Kiefer et al., 2006; Wang et al., 2013; Romahn et al., 2014), highlighting the importance of Southern Ocean intermediate water masses for interhemispheric

*Correspondence: N. Rippert, as above.

E-mail: nadine.rippert@awi.de coupling. Böning and Bard (2009) showed that SAMW-AAIW is even transported into the Arabian Sea. An imprint of SAMW-AAIW on Mg/Ca reconstructions in the eastern Indian Ocean also appears to be evident (Mohtadi et al., 2010).

When Southern Ocean water masses circulate in the Indian Ocean they affect the intermediate waters and thereby the thermocline. The thermocline acts as a barrier layer. It is one of the most important hydrographic controls on the availability of food, as food particles falling from the surface concentrate at this thermal gradient (Katz et al., 2010). However, the longterm variability of the thermocline as well as the geographical extent and influences of Southern Ocean water masses on stratification changes, especially in the tropical western Indian Ocean, are still poorly known due to a paucity of highresolution studies. Therefore, the overall objective of this study is to investigate whether the tropical western Indian Ocean surface and thermocline waters are affected by a connection via ocean water masses to the high latitudes. Furthermore, we want to (i) identify variations in surface and thermocline temperatures, (ii) investigate changes in the upper ocean water stratification, (iii) try to link these variations to the high latitudes, mainly to the Southern Ocean intermediate waters and (iv) compare thermocline waters of the western Indian Ocean with the eastern Indian Ocean.

Stable isotopes and $\mathrm{Mg} / \mathrm{Ca}$ temperatures of two planktonic foraminifera - the surface-dwelling Globigerinoides ruber (white) sensu stricto and the thermocline dweller Neogloboquadrina dutertrei-were produced. The former species is known to be a good indicator of subtropical-tropical surfacewater (upper $30 \mathrm{~m}$ ) conditions (Hemleben et al., 1989; Birch et al., 2013). Although G. ruber shows a strong seasonality, with highest fluxes in February-March in the south-west Indian Ocean, this species records flux-weighted annual mean mixed-layer sea surface temperatures (SSTs; Fallet et al., 2010, 2011). In contrast, $N$. dutertrei preferentially inhabits the upper to middle thermocline $(40-70 \mathrm{~m})$ and is 
often associated with the deep chlorophyll maximum (Fairbanks et al., 1982; Spero et al., 2003; Kiefer et al., 2006; Fallet et al., 2011). Despite exhibiting a sub-seasonal variation in shell flux, N. dutertrei favours no particular season (Fallet et al., 2011). Thus, by analysing the $\delta^{18} \mathrm{O}$ and $\mathrm{Mg} / \mathrm{Ca}$ ratios within these two planktonic foraminifera we are able to reconstruct variations in the thermal structure of the upper water column, as well as thermocline changes in the western equatorial Indian Ocean.

\section{Regional setting}

\section{Upper-ocean circulation}

Surface currents in the tropical western Indian Ocean are driven by seasonally reversing winds. Year-round the South Equatorial Current (SEC) flows westwards across the Indian Ocean (Fig. 1; Schott et al., 2002; Beal et al., 2013). Near the east coast of Madagascar it splits into the two western boundary currents, the Northeast and Southeast Madagascar Current (NEMC and SEMC). The NEMC merges with the northward-flowing East African Coastal Current (EACC) - the dominant current in the study area (Schott et al., 2002).

During the summer monsoon (Fig. 1a) the EACC feeds the northward-flowing Somali Current (SC), which in turn appears as a set of eddies and gyres (e.g. the Great Whirl; Schott et al., 2009; Beal et al., 2013). At $4^{\circ} \mathrm{N}$, a part of the low-latitude SC turns offshore. This leads to strong Ekman transport away from the East African coastline and results in the strongest upwelling of the Indian Ocean (Schott et al., 2009).

In contrast, drifter and satellite data show that the SC changes directions and coils back across the equator during the dry north-east monsoon (Fig. 1b; Beal et al., 2013). It forms a confluence zone with the northward-flowing EACC at about $4{ }^{\circ} \mathrm{S}$ and turns seaward off the coast of Kenya to strengthen the eastward-flowing South Equatorial Countercurrent (Schott et al., 2009).

The modern sea surface in the south-west Indian Ocean has an average temperature of $\sim 27.6^{\circ} \mathrm{C}$ (Fallet et al., 2011), ranging from 25.5 to $28.7^{\circ} \mathrm{C}$ (Locarnini et al., 2013).

\section{Subsurface circulation}

The thermocline in the Indian Ocean has an average depth of about $110 \mathrm{~m}$ (Locarnini et al., 2013). It receives waters from several sources, including the SAMW-AAIW, the Red Sea Waters (RSW) and the Indonesian Intermediate Water (IIW; Beal et al., 2000; Schott et al., 2002; Fine et al., 2008) and supplies waters to the SEC (Kiefer et al., 2006; Böning and Bard, 2009).

Although Fine et al. (2008) have estimated that SAMWAAIW can only contribute up to $20 \%$ to the Indian Ocean intermediate waters in the present setting, the southernsourced waters effectively ventilate the thermocline, even in the Arabian Sea (You, 1998; Fine et al., 2008; Böning and Bard, 2009). You (1998), Fine et al. (2008) and Böning and Bard (2009) have thus concluded that IIW and RSW represent only minor ventilation sources for the Indian Ocean.

SAMW-AAIW spreads into the Indian Ocean via two pathways. The western branch within the subtropical gyre represents a small pathway. The eastern branch, near the west coast of Australia, provides a more significant inflow of SAMW-AAIW into the thermocline of the Indian Ocean (Böning and Bard, 2009). Hence, the thickest layers of SAMW-AAIW are also found in the eastern Indian Ocean (Talley, 1999). Initially, SAMW-AAIW is characterized by low salinities, low temperatures and elevated nutrient concentrations (Quadfasel and Schott, 1982; Böning and Bard, 2009). North of the SEC the southern water mass mixes with the low-salinity IIW from the Indonesian Throughflow (ITF; Böning and Bard, 2009). The thermocline water with the imprint of SAMW-AAIW can still be traced north of the equator by its relatively high oxygen content and low salinities and extends as far as the Arabian Sea, which agrees with You (1998) who found AAIW up to $5^{\circ} \mathrm{N}$ along the western boundary.

\section{Materials and methods}

\section{The sedimentary record of GeoB12610-2}

During R/V Meteor cruise M75/2 in 2008, gravity core GeoB12610-2 was retrieved at the northern end of the Pemba Channel off Tanzania $\left(04^{\circ} 49.00^{\prime} \mathrm{S}, 39^{\circ} 25.42^{\prime} \mathrm{E}\right.$, water depth of 399 m; Savoye et al., 2013).

The upper $3.3 \mathrm{~m}$ of the $7.6-\mathrm{m}$-long gravity core was sampled at 2-cm intervals, washed and sieved at a $63-\mu \mathrm{m}$ mesh size. We selected about 15 specimens of Globigerinoides ruber (white variety, morphotype sensu stricto) from the $250-350-\mu \mathrm{m}$ size fraction and 15 specimens of Neogloboquadrina dutertrei (5-5.5 chambers) from the coarse size fraction $(425-475 \mu \mathrm{m})$ for the stable isotope measurements and analysis of trace element ratios, respectively.

\section{Age model}

The core chronology is based on seven accelerator mass spectrometry (AMS) radiocarbon analyses performed on multispecies planktonic foraminifera at the Poznań Radiocarbon Laboratory (Poz) and the National Ocean Sciences Accelerator Mass Spectrometry Facility (NOSAMS, OS).

All ${ }^{14} \mathrm{C}$ ages were converted into calendar years using the software Calib 7.0.2 (Stuiver et al., 2005) with the Marine13 calibration curve (Reimer et al., 2013). A reservoir age of 150 years ( \pm 60 years) was used based on the eight geographically closest calibrations points (from Southon et al., 2002). All tie points are given in Table 1.

A continuous age-depth model was built using a Bayesian accumulation model within the $\mathrm{R}$ open-source statistical environment called 'BACON' (Blaauw and Christen, 2011). The model divides the core into subsections and models the accumulation rate between the tie-points. A mean accumulation rate of $100 \mathrm{~cm} \mathrm{a}^{-1}$ (acc. mean $=100$, acc.shape $=1.5$ ) and the Gaussian distribution was used for the model. The minimum age limit was set to $-60(\mathrm{MinYr}=-60)$. All data points were calibrated using Marine13 and 76 sections.

\section{Stable isotope measurements}

Foraminiferal $\delta^{18} \mathrm{O}$ compositions were measured using a Finnigan-MAT 251 mass spectrometer at the Isotope Laboratory of the MARUM, University of Bremen. The isotopic composition of foraminiferal calcium carbonate was analysed on $\mathrm{CO}_{2}$ retrieved by treatment with phosphoric acid. An internal working standard was used (Burgbrohl $\mathrm{CO}_{2}$ gas), which has been calibrated against VPDB (Vienna Pee Dee Belemnite) using the NBS 19 standard. Consequently, all isotopic data given here are relative to the VPDB standard. The long-term analytical standard deviation is $\pm 0.07 \%$.

\section{Trace element analysis}

Prior to $\mathrm{Mg} / \mathrm{Ca}$ analyses, the planktonic foraminiferal shells were cleaned to remove any contaminated phases (e.g. clay or organic matter). We applied the cleaning method introduced by Barker et al. (2003); consisting of crushing the foraminiferal shells, clay removal using five ultra-pure water washes and two methanol washes, followed by the removal of organic 

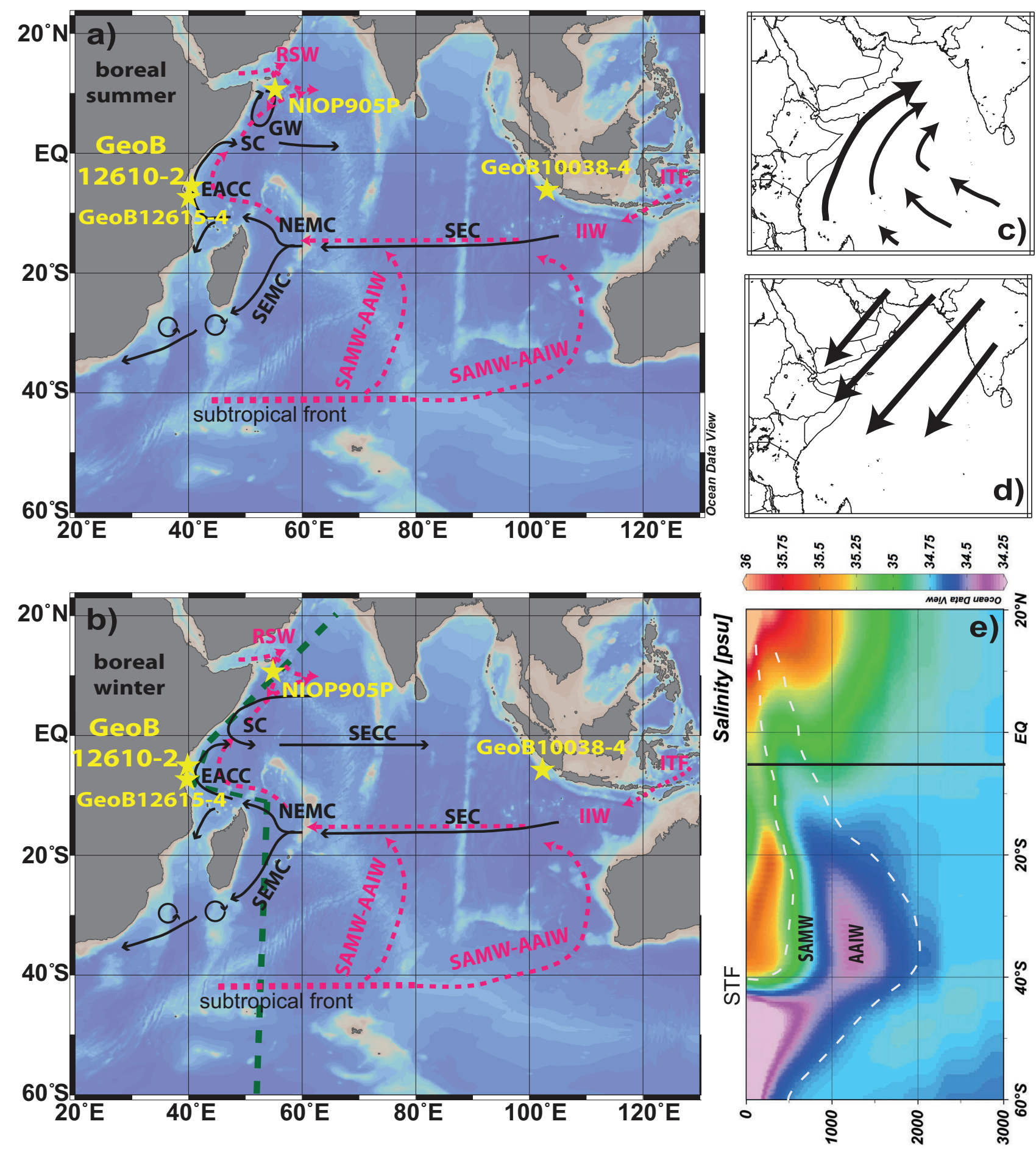

[u] ypdəव

Figure 1. Schematic representation of climatic conditions in the western Indian Ocean indicating surface currents (solid black lines) and thermocline currents (purple dashed lines) in the western Indian Ocean during (a) boreal summer (summer monsoon) and (b) boreal winter (winter monsoon). The position of core GeoB12610-2 and reference cores GeoB12615-4 (Romahn et al., 2014), NIOP 905P (Ivanova, 2000) and GeoB10038-4 (Mohtadi et al., 2010) are marked with yellow stars. Current branches shown are the South Equatorial Current (SEC), Northeast and Southeast Madagascar Current (NEMC and SEMC), East African Coastal Current (EACC), Somali Current (SC), South Equatorial Countercurrent (SECC), Great Whirl (GW), Red Sea Water (RSW), Indonesian Intermediate Water (IIW) from the Indonesian Throughflow (ITF) and Subantarctic Mode Water and Antarctic Intermediate Water (SAMW-AAIW; after Shapiro and Meschanov, 1991; Schott et al., 2002; Mohtadi et al., 2010). Wind conditions are shown during (c) boreal summer and (d) boreal winter (after Verschuren et al., 2009). (e) Salinity profile along the coast of Africa (green line in (b)) with the position of core GeoB12610-2 and the penetration of SAMW-AAIW (after Böning and Bard, 2009). Maps and transect were generated with Ocean Data View (Schlitzer, 2012) using data from World Ocean Atlas 2013. This figure is available in colour online at wileyonlinelibrary.com.

matter via two oxidation steps (with alkali-buffered $1 \% \mathrm{H}_{2} \mathrm{O}_{2}$ ). All samples were then dissolved in $0.075 \mathrm{M}$ QD $\mathrm{HNO}_{3}$, centrifuged for $10 \mathrm{~min}$ at 6000 r.p.m. and finally diluted.

Trace element concentrations were measured using an inductively coupled plasma optical emission spectrometer
(ICP-OES, Agilent Technologies, 700 Series with ASX-520 Cetac autosampler and micro-nebulizer) at the MARUM, University of Bremen. Elemental concentrations (reported in mmol mol ${ }^{-1}$ ) were inferred from analysing ${ }^{25} \mathrm{Mg}$ and ${ }^{43} \mathrm{Ca}$ at low instrument resolution. The instrumental precision was 
Table 1. AMS ${ }^{14} \mathrm{C}$ ages and calendar ages of sediment core GeoB12610-2.

\begin{tabular}{|c|c|c|c|c|}
\hline Laboratory ID & Core depth $(\mathrm{cm})$ & ${ }^{14} \mathrm{C}$ age $\left({ }^{14} \mathrm{C}\right.$ a BP $)$ & Calibrated age (cal a BP) ${ }^{*}$ & $\begin{array}{c}1 \sigma \text { cal age range (relative area } \\
\text { probability distribution) }{ }^{+}\end{array}$ \\
\hline Poz-30414 & 2 & $875 \pm 30$ & 369 & 300-429 (1.0) \\
\hline Poz-48031 & 56 & $4565 \pm 35$ & 4585 & $4475-4695$ (1.0) \\
\hline OS-81337 & 122 & $7650 \pm 40$ & 7960 & $7872-8028(1.0)$ \\
\hline Poz-48026 & 172 & $10650 \pm 110$ & 11682 & $11400-11916$ (1.0) \\
\hline OS-81338 & 230 & $14500 \pm 50$ & 16913 & $16767-17068$ (1.0) \\
\hline Poz-48029 & 310 & $26050 \pm 200$ & 29618 & 29 286-29 903 (1.0) \\
\hline Poz-48030 & 380 & $41800 \pm 1100$ & 44699 & $43704-45611$ (1.0) \\
\hline
\end{tabular}

${ }^{*}$ The ${ }^{14} \mathrm{C}$ ages were calibrated using the software Calib 7.0.2 (Stuiver et al., 2005) and the Marine13 calibration curve (Reimer et al., 2013) and a reservoir age of 150 years ( \pm 60 years).

${ }^{+} 1 \sigma$ encloses $68.3 \%$ of the probability distribution (Stuiver et al., 1998). Values in parentheses indicate the relative area under the probability distribution.

determined using an external standard $(\mathrm{Mg} / \mathrm{Ca}=2.29 \mathrm{mmol}$ $\mathrm{mol}^{-1}$ ), run after every fifth sample. The relative standard deviation of this external standard was $\pm 0.13 \%$. An ECRM 752-1 standard with a reported $\mathrm{Mg} / \mathrm{Ca}$ ratio of $3.84 \mathrm{mmol}$ $\mathrm{mol}^{-1}$ was measured at the beginning of the analysis and served as a calibration. Replicate measurements of $G$. ruber $(n=2)$ and $N$. dutertrei $(n=17)$ revealed standard deviations of 0.05 and $0.03 \mathrm{mmol} \mathrm{mol}^{-1}$, respectively.

We determined the effectiveness of the cleaning procedure by analysing the covariance between $\mathrm{Mg} / \mathrm{Ca}$ and $\mathrm{Al} / \mathrm{Ca}$ or $\mathrm{Fe} /$ Ca (Supporting information, Appendix S1). One sample of $G$. ruber $(154 \mathrm{~cm})$ revealed high $\mathrm{Al} / \mathrm{Ca}$ and $\mathrm{Fe} / \mathrm{Ca}$ ratios and hence was excluded from further analysis. The $\mathrm{Mg} / \mathrm{Ca}$ temperature estimates of $N$. dutertrei were free of contaminant phases.

\section{Reconstruction of past temperatures}

The $\mathrm{Mg} / \mathrm{Ca}$ ratios were converted into temperatures using species-specific equations. For G. ruber $(250-350 \mu \mathrm{m})$ the calibration equation of Dekens et al. (2002) was used:

$\mathrm{Mg} / \mathrm{Ca}=0.38( \pm 0.02) * \exp (0.09 * T)$.

For $N$. dutertrei $(350-500 \mu \mathrm{m})$ we applied the equation of Anand et al. (2003):

$\mathrm{Mg} / \mathrm{Ca}=0.342( \pm 0.012) * \exp (0.09 * T)$.

We have chosen these species-specific calibration equations as the derived core top temperatures were closest to mean annual satellite SST in the south-west Indian Ocean $\left(27.6^{\circ} \mathrm{C}\right.$; Fallet et al., 2011) and $25.7^{\circ} \mathrm{C}$ at $60-\mathrm{m}$ water depth (Locarnini et al., 2013). A more detailed description of the choice of the calibration curve is given in supporting Appendix S2.

The error of the temperature reconstruction was calculated by propagating the error inserted by the $\mathrm{Mg} / \mathrm{Ca}$ measurements and the $\mathrm{Mg} / \mathrm{Ca}$ temperature calibration (see Mohtadi et al., 2014 for details). The calculated errors are on average $1.17^{\circ} \mathrm{C}$ for the G. ruber and $0.72{ }^{\circ} \mathrm{C}$ for the $\mathrm{N}$. dutertrei temperature estimates (see Fig. 4).

Calcite dissolution lowers the initial signal of $\mathrm{Mg} / \mathrm{Ca}$ in a foraminiferal shell. As our core site lies at 399-m water depth, the palaeotemperature estimates are unaffected by dissolution.

\section{Modelling the timing of deglaciation}

To estimate whether there is a difference between the species and between $\delta^{18} \mathrm{O}$ and $\mathrm{Mg} / \mathrm{Ca}$ at the start of the deglaciation warming, we used RAMPFIT version 1.10 (Mudelsee, 2000). RAMPFIT uses weighted least-squares regression and bruteforce search to determine the two break points between two assumed equilibrium climate states. Time-dependent standard deviation provides the weights for the least-squares regression. Non-parametric stationary bootstrap re-sampling was applied to estimate uncertainties in the timing of the deglaciation. Age model uncertainties were not taken into account (Mudelsee, 2000).

\section{Results}

The age model of the studied section of sediment core GeoB12610-2 for the last $35 \mathrm{ka}$ is based on seven AMS ${ }^{14} \mathrm{C}$ age control points and a Bayesian accumulation model (Table 1; Fig. 2). The average sedimentation rate is $11.1 \mathrm{~cm}$ $\mathrm{ka}^{-1}$. However, a stepwise increase from a minimum of $5.8 \mathrm{~cm} \mathrm{ka}{ }^{-1}$ between 35 and $17.11 \mathrm{ka}$ to a maximum of $19.3 \mathrm{~cm} \mathrm{ka}^{-1}$ between 8 and $4.3 \mathrm{ka}$ is observed (Fig. 2).

In general, stable oxygen isotope values of both $G$. ruber and $N$. dutertrei record the last glacial-interglacial change.

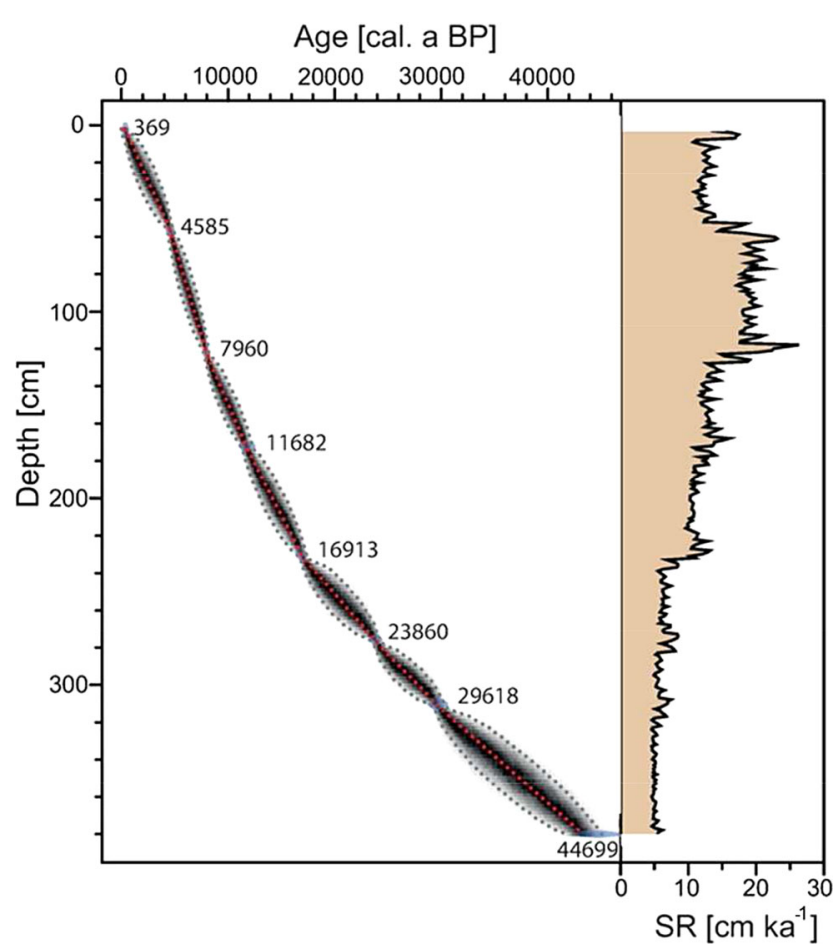

Figure 2. Age-depth plot and sedimentation rate (SR) of sediment core GeoB12610-2. The age-depth relationship was built with a Bayesian approach using the software BACON (Blaauw and Christen, 2011). In blue is the distribution of the individual dates; the best model is shown by the red dotted line and $95 \%$ probability interval by grey dotted lines. This figure is available in colour online at wileyonlinelibrary.com. 
Both curves show slight increases of about $0.5 \%$ (from -1.1 to $-0.6 \%$ and from -0.1 to $0.6 \%$, respectively) between 35 and $24 \mathrm{ka}$ (Fig. 3a,b). The following stable phase ends with a deglacial decrease of about $1.4 \%$ to average $\delta^{18} \mathrm{O}$ values of about $-2.0 \%$ for $G$. ruber in the Holocene. N. dutertrei records a continuous decreasing trend still in the Holocene, which is why no ramp function with RAMPFIT could be applied to the $\delta^{18} \mathrm{O}$ curve of $N$. dutertrei. A pronounced short positive excursion in the $G$. ruber $\delta^{18} \mathrm{O}$ record is visible from 12.4 to $11.4 \mathrm{ka}$, while the $\delta^{18} \mathrm{O}$ record of $N$. dutertrei does not show significant changes.

Shell $\mathrm{Mg} / \mathrm{Ca}$ ratios of $G$. ruber varied between 3.7 and $4.4 \mathrm{mmol} \mathrm{mol}^{-1}$ (corresponding to 25.0 and $27.1^{\circ} \mathrm{C}$, respectively) during the glacial period (Fig. 3c) and reached values between 4.3 and $5.2 \mathrm{mmol} \mathrm{mol}^{-1}$ (equivalent to 26.9 and $29.0^{\circ} \mathrm{C}$, respectively) during the Holocene. The $\mathrm{Mg} / \mathrm{Ca}$ ratios, and thus the temperatures, record a difference between the glacial period and the Holocene of on average $0.6 \mathrm{mmol}$ $\mathrm{mol}^{-1}$ and $1.5^{\circ} \mathrm{C}$.

The $\mathrm{Mg} / \mathrm{Ca}$ ratios of $\mathrm{N}$. dutertrei are lower than those of $G$. ruber (Fig. $3 \mathrm{~d}$ ). Values of $N$. dutertrei oscillated between 2.0 and $2.7 \mathrm{mmol} \mathrm{mol}^{-1}$ (equivalent to 19.7 and $22.9{ }^{\circ} \mathrm{C}$, respectively) during the glacial and fluctuated between 2.3 and $3.4 \mathrm{mmol} \mathrm{mol}^{-1}$ (corresponding to 21.3 and $25.5^{\circ} \mathrm{C}$, respectively) during the Holocene. A distinct short-term period of lower ratios of around $2.7 \mathrm{mmol} \mathrm{mol}^{-1}$ (and thus lower temperatures of around $22.9^{\circ} \mathrm{C}$ ) appears between 13.6 and $12 \mathrm{ka}$, with higher ratios (average of $3.3 \mathrm{mmol} \mathrm{mol}^{-1}$ ) either side and hence higher temperatures (average $25^{\circ} \mathrm{C}$ ). The amplitude between the glacial and the modern value in the thermocline is larger than that of the surface water $(0.83-$ $\left.0.59 \mathrm{mmol} \mathrm{mol}^{-1}\right)$, giving a larger temperature difference as well $\left(3.5-1.5^{\circ} \mathrm{C}\right.$, respectively).

The timing of the deglaciation was detected using a ramp regression analysis (supporting Appendix S3). Because $\delta^{18} \mathrm{O}_{G}$. ruber shows a trend during the glacial and the Late Holocene, data younger than $4.1 \mathrm{ka}$ and older than $23.7 \mathrm{ka}$ were excluded from the ramp regression analysis. RAMPFIT estimated the onset of the deglaciation at $17.62 \pm 0.34 \mathrm{ka}$. The

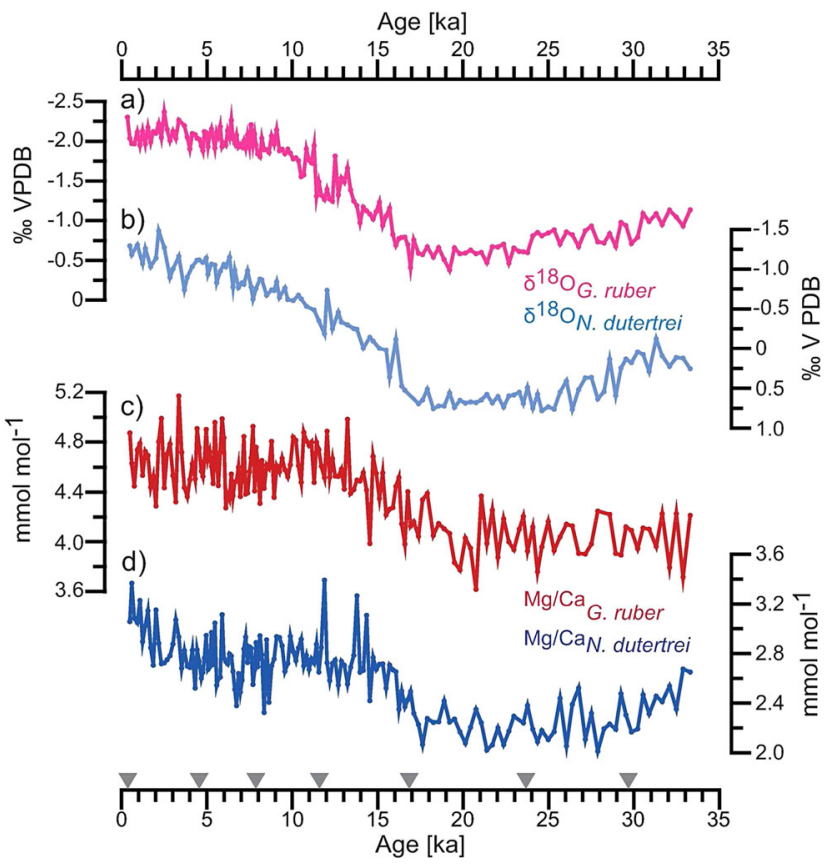

Figure 3. Measured stable oxygen isotope $(\mathrm{a}, \mathrm{c})$ and $\mathrm{Mg} / \mathrm{Ca}$ ratios (b, d) of $G$. ruber and N. dutertrei and age tie points (grey triangles) in sediment core GeoB12610-2. This figure is available in colour online at wileyonlinelibrary.com. transition started earlier in the $\mathrm{Mg} / \mathrm{Ca}$ record, having a break point at $19.49 \pm 0.42 \mathrm{ka}$, thereby showing that different climatic forcings trigger $\delta^{18} \mathrm{O}$ and $\mathrm{Mg} / \mathrm{Ca}$. The $\mathrm{Mg} / \mathrm{Ca}$ of the thermocline records a similar transition point to $\delta^{18} \mathrm{O}_{G}$. ruber, making it undistinguishable to say which of these two records experienced changes first. However, RAMPFIT showed that there is a difference between species $(\mathrm{Mg} / \mathrm{Ca}$ record of $G$. ruber and $\mathrm{N}$. dutertrei) and between $\delta^{18} \mathrm{O}$ and $\mathrm{Mg} / \mathrm{Ca}$ (both G. ruber curves).

\section{Discussion}

The stable oxygen isotope compositions and $\mathrm{Mg} / \mathrm{Ca}$-derived temperatures of planktonic foraminifera from different preferential habitat depths are frequently used as tools for reconstructing the vertical structure of the tropical upper ocean (e.g. Spero et al., 2003; Kiefer et al., 2006; Steph et al., 2009; Mohtadi et al., 2010; Birch et al., 2013). In the context of this work, we stick to definitions made by Tomczak (2001) regarding the depth of the mixed layer and the depth of the permanent thermocline. Hence, the temperature difference $(\Delta T)$ between shallow- and thermocline-dwelling foraminifera can serve as a proxy to reconstruct vertical temperature gradients within the upper water column (e.g. Steph et al., 2009). In principle, a smaller temperature difference $\left(\Delta T_{G}\right.$. ruber- $N$. dutertrei $)$ indicates a low thermal gradient, a deep mixed layer and thus a deep thermocline. By

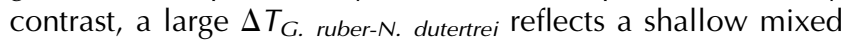
layer and hence a shallow thermocline. From these findings, similar to Mohtadi et al. (2010) and Steinke et al. (2014), we infer that down-core variations in shell geochemistry of the two species investigated in GeoB12610-2 can be used for the reconstruction of past changes in annual mean surface to thermocline gradients of the western Indian Ocean off Tanzania.

\section{Looking towards the high latitudes}

The stable isotope data of $G$. ruber show glacial/interglacial variations that match the northern high-latitude ice core GISP2 (Grootes and Stuiver, 1999) and sediment core NIOP 905P from the Arabian Sea (Ivanova, 2000; Fig. 4a-c). The onset of deglaciation in both NIOP 905P and GeoB12610-2 occurs roughly at the same time $(18.9$ and $19.5 \mathrm{ka}$, respectively). Light isotope values, and especially the shortterm increase towards heavier values in our core between 14.5 and $11.4 \mathrm{ka}$, can be correlated with the Bølling-Allerød (B-A) interstadial and the subsequent Younger Dryas (YD) cold period. This can be explained by the increase in the interhemispheric temperature gradient during the northern hemisphere cold, leading to a southward shift of the Intertropical Convergence Zone (ITCZ; Overpeck et al., 1996; Tierney et al., 2008). This causes a change in the amount of rainfall reaching our study area. Together with a possible weaker African and Asian monsoon as proposed by other studies (Tierney et al., 2008; Stager et al., 2011), the signal of the northern hemisphere is imprinted on our stable oxygen isotope record of the surface dweller. A connection to the northern hemisphere has been described in the Arabian Sea (e.g. Saher et al., 2007; Ziegler et al., 2010), where it is believed that oscillations in monsoon strength are related to high-frequency, large-amplitude fluctuations of the North Atlantic climate.

Evidently, the stable oxygen isotope and $\mathrm{Mg} / \mathrm{Ca}$ records are uncoupled. While the sea-surface oxygen isotopes indicate a connection to the northern high latitudes, the $\mathrm{Mg} / \mathrm{Ca}$-derived SSTs do not record changes that resemble the northern 


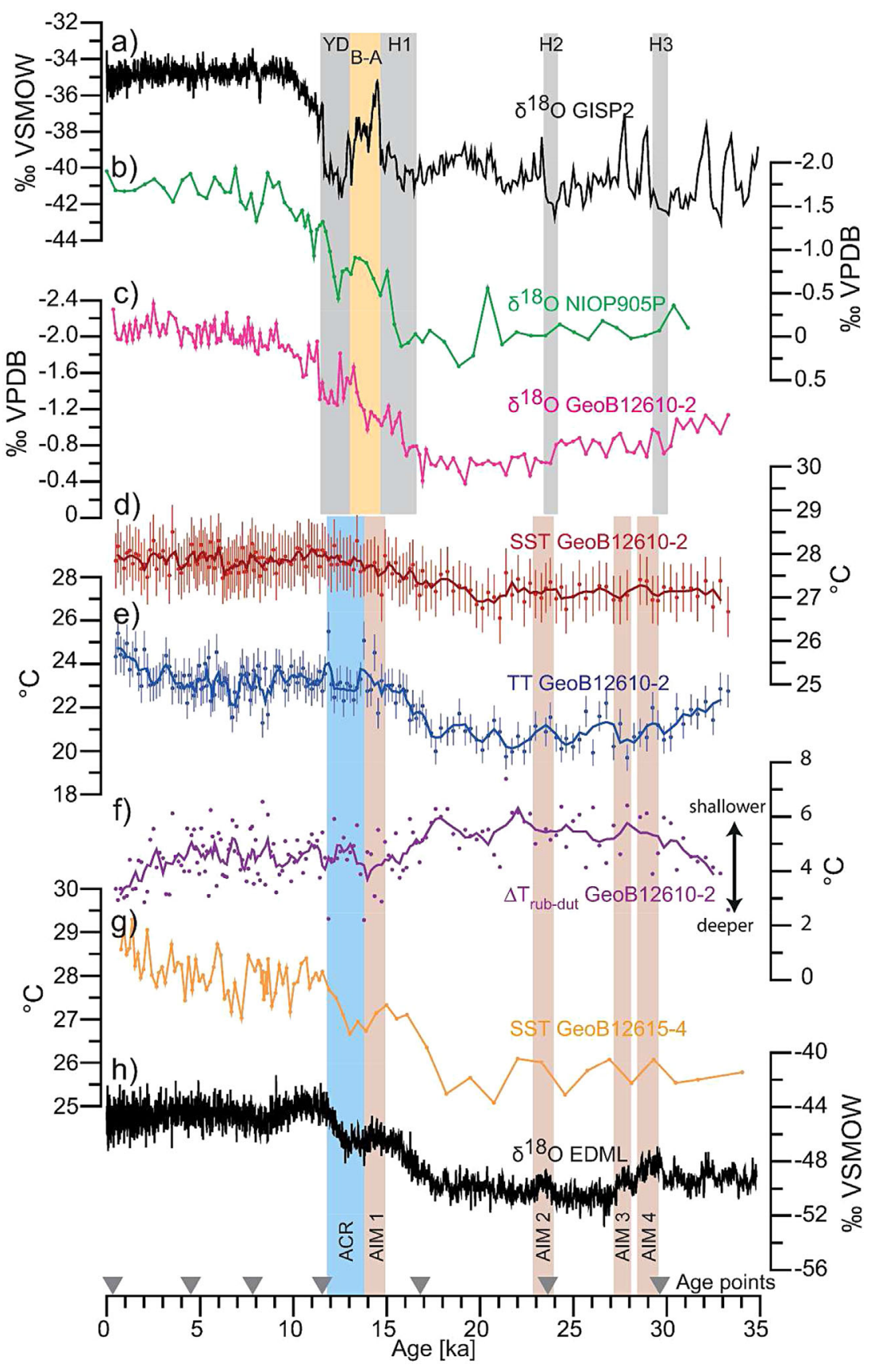

Figure 4. Comparison of reconstructed data from sediment core GeoB12610-2 with data from high latitudes, the Arabian Sea and off Tanzania. Graphs shown are (a) stable oxygen isotope curve of Greenland (GISP2, Grootes and Stuvier, 1999), (b) $\delta^{18} \mathrm{O}_{G}$ ruber offshore Somalia (NIOP 905P; Ivanova, 2000), (c) $\delta^{18} \mathrm{O}_{G}$. ruber GeoB12610-2, (d) $\mathrm{Mg} / \mathrm{Ca}_{G}$. ruber-derived SST variations in sediment core GeoB12610-2 with error bars and three-point running average (dark red line), (e) $\mathrm{Mg} / \mathrm{Ca}_{\mathrm{N}}$. dutertreiderived thermocline temperatures (TT) of core GeoB12610-2 with error bars and three-point running average (dark blue line), (f) temperature difference $(\Delta \mathrm{T})$ between the sea surface and the thermocline of GeoB12610-2, (g) $\mathrm{Mg} / \mathrm{Ca}_{G}$. ruber derived SST variations in sediment core GeoB12615-4 (Romahn et al., 2014) and (h) the stable isotope curve of Antarctica (EDML; EPICA, 2010). YD, Younger Dryas; B-A, Bølling-Allerød interstadial; H1-3, Heinrich stadials; ACR, Antarctic Cold Reversal; AIM 1-4, Antarctic Isotope Maxima. This figure is available in colour online at wileyonlinelibrary.com. hemisphere record. It is accepted that stable oxygen isotope records of surface-dwelling foraminifera bear the imprint of temperature and the isotopic signature of surface water masses. The latter can be affected by evaporation and precipitation, terrestrial runoff or water mass advection. In our particular case, it seems that the isotopic signature of surface waters is influenced by seasonal migration of the ITCZ and associated rain belts (Rozanski et al., 1996; Verschuren et al., 2009). Conversely, the $\mathrm{Mg} / \mathrm{Ca}$ record of $G$. ruber seems to reflect solely a temperature signal that is unaffected by the water mass properties discussed before. Our Mg/Ca record does not contain evidence of cold events, such as Heinrich Events or the YD, nor warm events, such as the B-A. Instead, a slight decrease in surface temperatures of $0.3{ }^{\circ} \mathrm{C}$ was recorded just before the YD (Fig. 4d). This drop is even more pronounced (average $0.9{ }^{\circ} \mathrm{C}$ ) in the thermocline record of GeoB12610-2 (Fig. 4e) and can be attributed to the Antarctic Cold Reversal (ACR), indicating an influence of Southern Ocean intermediate water masses on thermocline waters off Tanzania. During the glacial period there is an apparent correlation between our thermocline record and the
Antarctic EDML curve, suggesting that the thermocline waters of the Indian Ocean must have had a higher proportion of Southern Ocean intermediate waters than at present. A higher production and export of SAMW-AAIW during glacial times has already been shown in the Atlantic, Pacific and Indian Oceans (e.g. Pahnke et al., 2008; Jung et al., 2009). The water mass would be transported via 'ocean tunnels' to the equatorial Indian Ocean where it would upwell and feed the SEC then the EACC, and subsequently reach our study area. Thus, the greater imprint of Southern Ocean water masses can be seen in the thermocline, as our data records reveal. This confirms the investigations by Kiefer et al. (2006) which identified the upwelling imprint as a clear cool anomaly of $\sim 6^{\circ} \mathrm{C}$ in the thermocline.

In addition to an increased production of SAMW-AAIW during glacial times (Pahnke et al., 2008; Jung et al., 2009) as a cause for the close correlation between the southern high latitudes and the western tropical Indian Ocean, a greater dispersion of these Southern Ocean water masses could also contribute to the signal. Today, the intermediate water in the Indian Ocean is formed by three components: AAIW, RSW 
and IIW (Beal et al., 2000; Schott et al., 2002; Fine et al., 2008). RSW is characteristically very highly saline and is formed when water overflows the Strait of Bab el Mandeb (Beal et al., 2000). This strait forms the only connection between the Red Sea and the open ocean (Rohling, 1994). The water mass then spreads along the African continental slope as far as the Mozambique Channel at a similar density interval as the low-salinity AAIW (Beal et al., 2000). The sill at the Strait of Bab el Mandeb was only $17 \mathrm{~m}$ deep and about $11 \mathrm{~km}$ wide during the last glacial with a sea level lowstand of $\sim 120 \mathrm{~m}$ (Fairbanks, 1989; Rohling, 1994; Siddall et al., 2003), resulting in a diminished export of RSW. The glacial sea-level lowstand would also affect the export of waters from the Pacific into the Indian Ocean via the ITF. At present, four passages with different sill depths control the intensity of IIW through the ITF (Kuhnt et al., 2004). Modelling work suggests that the surface flow remained nearly unchanged, but thermocline flow was reduced during the glacial period (Kuhnt et al., 2004). Yet, the net flow from the Pacific to the Indian Ocean via the IIW was probably reduced because peak flow through the ITF occurs in the thermocline (Gordon et al., 2003). With a reduced contribution of the IIW to the SEC and diminished RSW, SAMW-AAIW could spread to a larger extent into the Indian Ocean.

The cooler thermocline waters caused a change in the depth of the thermocline. With the nearly constant SST and the decrease in thermocline temperatures during the last glacial, stratification of the upper-ocean water structure increased and the thermocline shoaled (Fig. 4f). During the Last Glacial Maximum, the depth of the thermocline was shallower than at present, and with the onset of the termination it started to deepen. With the pronounced cold excursion, i.e. the ACR, the thermocline experienced a pulse of low temperatures and the depth of the thermocline shoaled again.

Our SST record shows only a slight resemblance to the EDML curve. As our core is not located in the open ocean, the influence from Southern Ocean water masses might not be significant in the surface water. However, new $\mathrm{Mg} / \mathrm{Ca}$ data and reconstructions on $G$. ruber slightly to the south of our core site in the open ocean (GeoB12615-4) also reveal that even surface waters off Tanzania might be influenced by SAMW-AAIW (Fig. 4g; Romahn et al., 2014). Mg/Ca $\mathrm{C}_{G}$ ruber reconstructions from the Mozambique Channel also support the influence of SAMW-AAIW on SST, showing that the coldseason SSTs were impelled by climatic changes in the southern hemisphere (Wang et al., 2013). Furthermore, an impact of SAMW-AAIW on surface waters even into the Arabian Sea has previously been suggested (Huguet et al., 2006).

The surface temperatures show a warming trend at the start of the deglaciation some years before the thermocline temperatures or the $\delta^{18} \mathrm{O}_{G}$. ruber record show changes (Fig. 4c-e). With the onset of the retreat of the West Antarctic Ice Sheet at 20.88 ka (Klages et al., 2014) the imprint of SAMW-AAIW diminishes. As the thermocline was bathed mainly by waters from the south during that period, small variations are not visible in the record. However, the imprint of SAMW-AAIW on surface temperatures reduces and together with the increased northern summer insolation the surface temperatures increase. The $\delta^{18} \mathrm{O}_{G}$. ruber and thermocline temperatures record the onset of the termination $\sim 2$ ka later than the surface temperatures. By that time the reduction of SAMW-AAIW is distinct, which is why the thermocline warms. Synchronously, insolation strengthens further, possibly resulting in atmospheric reorganization, a shift in the position of the ITCZ and thus to a change in the surface $\delta^{18} \mathrm{O}_{G}$. ruber record. Combining all these data, we conclude that Southern Ocean intermediate waters affect surface waters in the western Indian Ocean, but that a larger influence appears in the thermocline, thereby affecting the depth of the thermocline.

\section{Looking towards the eastern Indian Ocean}

To understand the composition of the thermocline in the western Indian Ocean, and hence the changes in the thermocline at our core site, it is necessary to look at the eastern tropical Indian Ocean. Therefore, we compare our data with records from sediment core GeoB10038-4 off south-west Sumatra (Mohtadi et al., 2010).

It is apparent that the thermocline has the same temperature range in the western and eastern regions of the Indian Ocean during the glacial period (Fig. 5a). However, the temperatures differ more widely during the following deglaciation. In the western Indian Ocean the thermocline

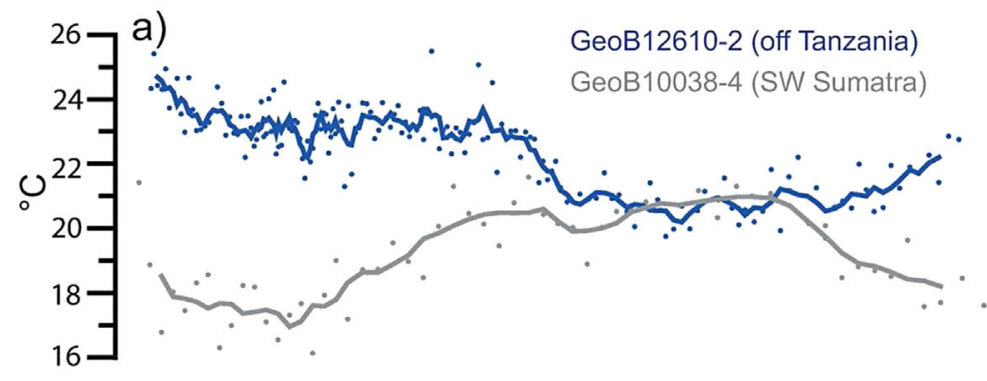

Figure 5. (a) $\mathrm{Mg} / \mathrm{Ca}$-derived thermocline temperature curve of $N$. dutertrei from off Tanzania (GeoB12610-2, blue with five-point running average) and off Sumatra (GeoB10038-4, light grey with five-point running average, Mohtadi et al., 2010). (b) Temperature gradient between the surface dweller and the thermocline dweller indicating the depth of the thermocline for GeoB12610-2 (violet and five-point running average) and GeoB10038-4 (dark grey). This figure is available in colour online at wileyonlinelibrary.com.

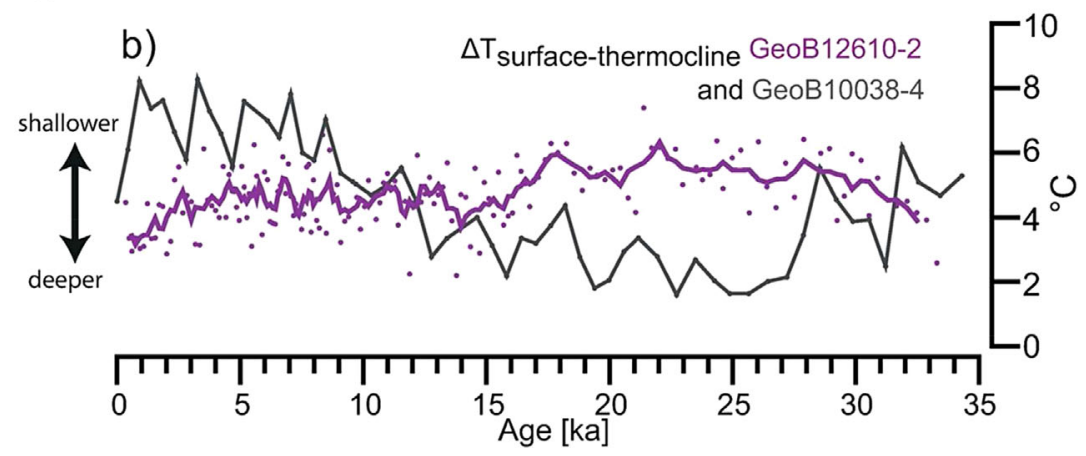


experienced higher temperatures, whereas the eastern Indian Ocean records cooler conditions. Mohtadi et al. (2010) argue that the southern hemisphere frontal system was shifted northward during the glacial, thereby moving the formation area of SAMW towards lower latitudes and inducing warmer thermocline waters in the Indian Ocean. The southward retreat of the frontal system during the deglaciation led to the incorporation of cooler waters into the SAMW. The lower temperatures in the SAMW would then also affect the thermocline waters at our study site off Tanzania. However, we see an increase in thermocline temperature instead of a decrease during the deglaciation. Therefore, the southward retreat of the frontal system and the formation of SAMW in cooler waters cannot be the primary explanation for the lowering of thermocline temperatures off Sumatra.

At present, four passages control the intensity of the ITF (Kuhnt et al., 2004). The ITF is a narrow band of low-salinity, warm water that transports excess heat from the Western Pacific Warm Pool into the Indian Ocean and also feeds the SEC (Gordon and Fine, 1996; Kuhnt et al., 2004). As suggested by modelling work (Kuhnt et al., 2004), the reduced sill depth of these oceanic passages resulted in a nearly unchanged surface through-flow but a reduction of thermocline flow during the last glacial. Yet, the net flow from the Pacific to the Indian Ocean via the ITF was reduced because the peak flow of the ITF occurred in the thermocline (Gordon et al., 2003). With a reduced contribution of the ITF to the SEC, SAMW-AAIW spread to a larger extent into the Indian Ocean. With rising sea level the shelf areas were again flooded (e.g. Kuhnt et al., 2004), allowing more water to enter the eastern Indian Ocean from the Pacific via the ITF, thereby also partially increasing the SSTs in the eastern Indian Ocean (see Mohtadi et al., 2010). Although no obvious and persistent upwelling conditions offshore Sumatra are detected during the last 35 ka (e.g. Murgese et al., 2008), renewed upwelling bringing colder waters from the deep ocean might have taken place during the deglaciation and Holocene, causing a decrease in thermocline temperatures off Sumatra. By contrast, we see an increase in thermocline temperatures in GeoB12610-2 because of the reduced contribution of SAMW-AAIW and a larger proportion of warm RSW and IIW in the Indian Ocean thermocline.

Due to the increase in thermocline temperatures at our core site, the gradient between the sea surface and the thermocline decreased by $2{ }^{\circ} \mathrm{C}$, which probably led to a deepening of the thermocline. Our results are in good agreement with model simulations, which show that the weakened Asian monsoon during glacial times resulted in a significant shoaling of the mean tropical thermocline in the central and western Indian Ocean (Liu et al., 2007). In the eastern Indian Ocean the data show the opposite trend, i.e. a deeper thermocline than in the western Indian Ocean and a shoaling during the deglaciation and Holocene (Fig. 5b). From the last glacial to present, it appear that the depth of the thermocline reverses from deep in the east and shallow in the west to shallow in the east and deep in the west, probably due to the changing composition of the thermocline waters and upwelling offshore Sumatra.

\section{Conclusions}

The $\mathrm{Mg} / \mathrm{Ca}$ temperature reconstructions of both the surfacedwelling $G$. ruber and subsurface-dwelling $N$. dutertrei in core GeoB12610-2 allow reconstruction of the thermal gradient and hence of stratification of the water column. In the western tropical Indian Ocean the thermocline was shallower during glacial periods than it is today, and deepened significantly during the termination. Thermocline temperatures obtained from GeoB12610-2 correlate quiet well with the Antarctic EDML temperature curve. The link between the western Indian Ocean thermocline and the Antarctic is generated by southern hemisphere intermediate water masses (SAMW-AAIW) via defined pathways (called 'ocean tunnels') into the Indian Ocean. The amount of RSW and water from the ITF is reduced during the glacial period due to a lowered sea level. This, together with a higher production of SAMW-AAIW due to a diminished production of North Atlantic Deep Water, means that SAMW-AAIW thus makes up a higher proportion of the SEC. With the rise of sea level towards the Holocene the contribution of intermediate waters changes, making the correlation between the thermocline waters of the western Indian Ocean and the Antarctic EDML curve barely traceable.

\section{Supporting Information}

Additional supporting information may be found in the online version of this article.

Appendix S1. Effectiveness of the cleaning procedure.

Appendix S2. Choice of $\mathrm{Mg} / \mathrm{Ca}$ calibration.

Appendix S3. Estimating the time of termination using RAMPFIT.

Supplementary data are available on PANGEA at http://dx.doi. org/10.1594/PANGAEA.841927.

Acknowledgements. We thank the captain, crew and participants of R/V Meteor cruise M75/2 for retrieving the studied material. Monika Segl and Mahyar Mohtadi are acknowledged for their assistance in stable isotope and radiocarbon dating. We are grateful to Stephan Steinke, Jeroen Groeneveld and Cornelia Kwiatkowski for their help with the $\mathrm{Mg} / \mathrm{Ca}$ preparation, error analysis and valuable discussions on early versions of the manuscript. We thank Matthias Prange and Andrea Klus for their assistance with RAMPFIT. Walter Hale is thanked for proofreading. This work was funded through DFG-Research Center/Cluster of Excellence 'The Ocean in the Earth System'. We thank the editor Antony Long and two anonymous reviewers for their help in improving the quality of the manuscript.

Abbreviations. AAIW, Antarctic Intermediate Water; ACR, Antarctic Cold Reversal; AIM, Antarctic Isotope Maxima; AMS, accelerator mass spectrometry; B-A, Bølling-Allerød; EACC, East African Coastal Current; GW, Great Whirl; IIW, Indonesian Intermediate Water; ITCZ, Intertropical Convergence Zone; ITF, Indonesian Throughflow; NEMC, Northeast Madagascar Current; RSW, Red Sea Water; SAMW, Subantarctic Mode Water; SC, Somali Current; SEC, South Equatorial Current; SEMC, Southeast Madagascar Current; SST, sea surface temperature; YD, Younger Dryas.

\section{References}

Anand P, Elderfield H, Conte MH. 2003. Calibration of $\mathrm{Mg} / \mathrm{Ca}$ thermometry in planktonic foraminifera from a sediment trap time series. Paleoceanography 18: 1050.

Barker S, Greaves M, Elderfield H. 2003. A study of cleaning procedures used for foraminiferal $\mathrm{Mg} / \mathrm{Ca}$ paleothermometry. Geochemistry, Geophysics, Geosystems 4: 8407.

Beal LM, Hormann V, Lumpkin R et al. 2013. The response of the surface circulation of the Arabian Sea to monsoonal forcing. Journal of Physical Oceanography 43: 2008-2022.

Beal LM, Field A, Gordon AL. 2000. Spreading of Red Sea overflow waters in the Indian Ocean. Journal of Geophysical Research 105: 8549-8564.

Birch H, Coxall HK, Pearson PN et al. 2013. Planktonic foraminifera stable isotopes and water column structure: disentangling ecological signals. Marine Micropaleontology 101: 127-145. 
Blaauw M, Christen JA. 2011. Flexible paleoclimate age-depth models using an autoregressive gamma process. Bayesian Analysis 6: $457-474$.

Böning P, Bard E. 2009. Millennial/centennial-scale thermocline ventilation changes in the Indian Ocean as reflected by aragonite preservation and geochemical variations in Arabian Sea sediments. Geochimica et Cosmochimica Acta 73: 6771-6788.

Bostock HC, Opdyke BN, Williams MJW. 2010. Characterizing the intermediate depth waters of the Pacific Ocean using $813 \mathrm{C}$ and other geochemical tracer. Deep-Sea Research Part I 157: 847859.

Dekens PS, Lea DW, Pak DK et al. 2002. Core top calibration of $\mathrm{Mg} / \mathrm{Ca}$ in tropical foraminifera: refining paleotemperature estimation. Geochemistry, Geophysics, Geosystems 3: 1-29.

European Project for Ice Coring in Antarctica Community Members (EPICA). 2010. Stable oxygen isotopes of ice core EDML. PANGAEA, doi:10.1594/PANGAEA.754444

Fairbanks RG. 1989. A 17,000-year glacio-eustatic sea level record: influence of glacial melting rates on the Younger Dryas event and deep-ocean circulation. Nature 342: 637-642.

Fairbanks RG, Sverdlove M, Free R et al. 1982. Vertical distribution and isotopic fractionation of living planktonic foraminifera from the Panama Basin. Nature 298: 841-844.

Fallet U, Brummer G-J, Zinke J et al. 2010. Contrasting seasonal fluxes of planktonic foraminifera and impacts on paleothermometry in the Mozambique Channel upstream of the Agulhas Current. Paleoceanography 25: PA4223.

Fallet U, Ullgren JE, Castañeda IS et al. 2011. Contrasting variability in foraminiferal and organic paleotemperature proxies in sedimenting particles of the Mozambique Channel (SW Indian Ocean). Geochimica et Cosmochimica Acta 75: 5834-5848.

Fine RA, Smethie WM, Jr, Bullister JL et al. 2008. Decadal ventilation and mixing of Indian Ocean waters. Deep-Sea Research 55: 20-37.

Gordon AL, Fine RA. 1996. Pathways of water between the Pacific and Indian Oceans in the Indonesian Seas. Nature 379: 146-149.

Gordon AL, Susanto RD, Vranes K. 2003. Cool Indonesian Throughflow as a consequence of restricted surface layer flow. Nature 425: 824-828.

Gordon AL, Weiss RF, Smethie WM, Jr, et al. 1992. Thermocline and intermediate water communication between the South Atlantic and Indian Oceans. Journal of Geophysical Research 97: 7223-7240.

Grootes PM, Stuiver M. 1999. GISP2 Oxygen Isotope Data. doi:10.1594/PANGAEA.56094

Hemleben C, Spindler M, Anderson OR. 1989. Modern Planktonic Foraminifera. Springer: New York.

Huguet C, Kim JH, Damsté JSS et al. 2006. Reconstruction of sea surface temperature variations in the Arabian Sea over the last 23 kar using organic proxies (TEX86 and UK37). Paleoceanography 21: PA3003.

Ivanova E. 2000. Late Quaternary monsoon history and paleoproductivity of the western Arabian Sea. PhD Thesis, Free University Amsterdam.

Jung SJA, Kroon D, Ganssen G et al. 2009. Enhanced Arabian Sea intermediate water flow during glacial North Atlantic cold phases. Earth and Planetary Science Letters 280: 220-228.

Katz ME, Cramer BS, Franzese A et al. 2010. Traditional and emerging geochemical proxies in foraminifera. The Journal of Foraminiferal Research 40: 165-192.

Kessler WS. 2006. The circulation of the eastern tropical Pacific: a review. Progress in Oceanography 69: 181-217.

Kiefer T, McCave IN, Elderfield H. 2006. Antarctic control on tropical Indian Ocean sea surface temperature and hydrography. Geophysical Research Letters 33: L24612.

Klages JP, Kuhn G, Hillenbrand CD et al. 2014. Retreat of the West Antarctic Ice Sheet from the western Amundsen Sea shelf at a preor early LGM stage. Quaternary Science Reviews 91: 1-15.

Kuhnt W, Holbourn A, Hall R et al. 2004. Neogene history of the Indonesian Throughflow. In Continent-Ocean interactions within East Asia marginal seas. American Geophysical Union; 299320.

Liu X, Liu Z, Clemens S et al. 2007. A coupled model study of glacial Asian monsoon variability and Indian Ocean dipole. Journal of the Meteorological Society of Japan 85: 1-10.
Liu ZDC, Yang H. 2003. Extratropical control of tropical climate, the atmospheric bridge and oceanic tunnel. Geophysical Research Letters 30: 1029.

Locarnini, RA, Mishonov AV, Antonov JI et al. 2013. World Ocean Atlas 2013 Volume 1: Temperature. In NOAA Atlas NESDIS 73, Levitus S, Mishonov A (eds), National Oceanographic Data Center, $40 \mathrm{pp}$.

Mohtadi M, Lückge A, Steinke S et al. 2010. Late Pleistocene surface and thermocline conditions of the eastern tropical Indian Ocean. Quaternary Science Reviews 29: 887-896.

Mohtadi M, Prange M, Oppoe DW et al. 2014. North Atlantic forcing of tropical Indian Ocean climate. Nature 509: 76-80.

Mudelsee M. 2000. Ramp function regression: a tool for quantifying climate transitions. Computers and Geosciences 26: 293-307.

Murgese DS, De Deckker P, Spooner MI et al. 2008. A 35,000 year record of changes in the eastern Indian Ocean offshore Sumatra. Palaeogeography Palaeoclimatology Palaeoecology 265: 195-213.

Overpeck J, Anderson D, Trumbore S et al. 1996. The southwest Indian Monsoon over the last 18000 years. Climate Dynamics 12: 213-225.

Pahnke K, Goldstein SL, Hemming SR. 2008. Abrupt changes in Antarctic Intermediate Water circulation over the past 25,000 years. Nature Geosciences 1: 870-874.

Pena LD, Goldstein SL, Hemming SR et al. 2013. Rapid changes in meridional advection of Southern Ocean intermediate waters to the tropical Pacific during the last 30kyr. Earth and Planetary Science Letters 368: 20-32.

Quadfasel DR, Schott F. 1982. Water-mass distributions at intermediate layers off the Somali coast during the onset of the Southwest Monsoon, 1979. Journal of Physical Oceanography 12: 13581372.

Reimer PJ, Bard E, Bayliss A et al. 2013. IntCal13 and Marine13 radiocarbon age calibration curves $0-50,000$ years cal BP. Radiocarbon 55: 1869-1887.

Rohling EJ. 1994. Glacial conditions in the Red Sea. Paleoceanography 9: 653-660.

Romahn S, Mackensen A, Groeneveld J et al. 2014. Deglacial intermediate water reorganization: new evidence from the Indian Ocean. Climate of the Past 10: 293-303.

Rozanski K, Araguas-Araguas L, Gonfiantini R. 1996. Isotope patterns of precipitation in the East African region. In The Limnology, Climatology and Paleoclimatology of the East African Lakes, Johnson TC, Odada EO (eds). Gordon \& Breach: Amsterdam; 7993.

Saher MH, Peeters FJC, Kroon D. 2007. Sea surface temperatures during the SW and NE monsoon seasons in the western Arabian Sea over the past 20,000 years. Palaeogeography, Palaeoclimatology, Palaeoecology 249: 216-228.

Savoye B, Ridderinkhof H, Pätzold J et al. 2013. Western Indian Ocean Climate and Sedimentation - Cruise No. M75 - December 29, 2007-April 08, 2008 - Port Louis (Mauritius) - Cape Town (South Africa). DFG Senatskommission für Ozeanographie. METEOR - Berichte. M75, doi:10.2312/cr_m75

Schlitzer R. 2012. Ocean Data View. odv.awi.de.

Schott FA, Dengler M, Schoenefeldt R. 2002. The shallow overturning circulation of the Indian Ocean. Progress in Oceanography 53: 57103.

Schott FA, Xie S-P., McCreary JP, Jr. 2009. Indian Ocean circulation and climate variability. Reviews of Geophysics 47: RG1002.

Shapiro GI, Meschanov SL. 1991. Distribution and spreading of Red Sea Water and salt lens formation in the northwest Indian Ocean. Deep-Sea Research 38: 21-34.

Siddall M, Rohling EJ, Almogi-Labin A et al. 2003. Sea-level fluctuations during the last glacial cycle. Nature 423: 853-858.

Southon J, Kashgarian M, Fontugne $M$ et al. 2002. Marine reservoir corrections for the Indian Ocean and Southeast Asia. Radiocarbon 44: $167-180$.

Spero HJ, Mielke KM, Kalve EM et al. 2003. Multispecies approach to reconstructing eastern equatorial Pacific thermocline hydrography during the past 360 kar. Paleoceanography 18: 1022.

Stager JC, Ryves DB, Chase BM et al. 2011. Catastrophic drought in the Afro-Asian monsoon region during Heinrich event 1. Science 331: 1299-1302. 
Steinke S, Prange M, Feist C et al. 2014. Upwelling variability off southern Indonesia over the past two millennia. Geophysical Research Letters 41: 7684-7693.

Steph S, Regenberg M, Tiedemann R et al. 2009. Stable isotopes of planktonic foraminifera from tropical Atlantic/Caribbean core-tops: implications for reconstructing upper ocean stratification. Marine Micropaleontology 71: 1-19.

Stuiver M, Reimer PJ, Reimer RW. 2005. CALIB 5.0. http://calib.qub. ac.uk/calib/

Stuiver M, Reimer PJ, Bard E et al. 1998. Intcal98 radiocarbon age calibration, 24,000-0 cal BP. Radiocarbon 40: 1041-1083.

Talley LD. 1999. Some aspects of ocean heat transport by the shallow, intermediate and deep overturning circulations. In Mechanisms of Global Climate Change at Millennial Time Scales, Clark PU (ed.). American Geological Union; 1-22.

Tierney JE, Russell JM, Huang Y et al. 2008. Northern hemisphere controls on tropical southeast African climate during the past 60,000 years. Science 322: 252-255.
Tomczak M. 2001. Upper Ocean mean horizontal structure. In Elements of Physical Oceanography, Thorpe SA, Steele JH, Turekian KK (eds). Academic Press: New York; 252261.

Verschuren D, Sinninghe Damste JS, Moernaut J et al. 2009. Halfprecessional dynamics of monsoon rainfall near the East African Equator. Nature 462: 637-641.

Wang YV, Leduc G, Regenberg M et al. 2013. Northern and southern hemisphere controls on seasonal sea surface temperatures in the Indian Ocean during the last deglaciation. Paleoceanography 28: 619-632.

You Y. 1998. Intermediate water circulation and ventilation of the Indian Ocean derived from water-mass contributions. Journal of Marine Research 56: 1029-1067.

Ziegler M, L ourens LJ, Tuenter E et al. 2010. Precession phasing offset between Indian summer monsoon and Arabian Sea productivity linked to changes in Atlantic overturning circulation. Paleoceanography 25: PA3213. 